\title{
Nuclear and mitochondrial DNA-dependent RNA polymerases in bovine spermatozoa
}

\author{
N. B. Hecht and J. L. Williams \\ Department of Biology, Tufts University, Medford, Massachusetts 02155, U.S.A.
}

\begin{abstract}
Summary. DNA-dependent RNA polymerases have been solubilized from separated head and tail fractions from normal bovine spermatozoa and from spermatozoa carrying the 'decapitated sperm defect'. When enzyme extracts from separated heads and tails were chromatographed on DEAE-Sephadex, the head fraction was resolved into 2 distinguishable peaks eluting at about 0.11 and $0.15 \mathrm{M}-\left(\mathrm{NH}_{4}\right)_{2} \mathrm{SO}_{4}$ while the tail fraction yielded 4 distinct peaks eluting at about $0.11,0.15,0.255$ and $0.35 \mathrm{M}-\left(\mathrm{NH}_{4}\right)_{2} \mathrm{SO}_{4}$. Results identical to those observed for sperm tails were obtained with extracts prepared from highly purified mitochondria from bovine or murine heart or liver. Optimization of reaction parameters and inhibitor studies with $\alpha$ amanitin and rifampicin revealed strong similarities between eucaryotic nuclear RNA polymerases 1 and 2 and the 2 RNA polymerases associated with sperm heads. Similar experiments comparing the RNA polymerases from somatic mitochondria and sperm tails suggested the sperm tail enzymes were mitochondrial in origin.
\end{abstract}

\section{Introduction}

When incubated with RNA precursors, mammalian spermatozoa synthesize RNA (Abraham \& Bhargava, 1963; Premkumar \& Bhargava, 1972, 1973; MacLaughlin \& Terner, 1973; Betlach \& Erickson, 1976; Fuster, Farrell, Stern \& Hecht, 1977). Inhibitor and localization studies have led investigators to conclude that the RNA transcribed in ejaculated spermatozoa is of mitochondrial origin (Premkumar \& Bhargava, 1972, 1973). Fuster et al. (1977) have shown that the RNA polymerase activity in ejaculated bovine spermatozoa is mainly associated with the tail fraction of the spermatozoa, but separated sperm heads and tails are both capable of RNA transcription utilizing endogenous templates and enzymes (Hecht \& Williams, 1978). Differences in cation and temperature optima and differential responses to atractyloside, $\alpha$ amanitin, and rifamycin SV suggested that the head and tail fractions of the spermatozoa contained different RNA polymerases (Hecht \& Williams, 1978).

In this communication we seek to define the transcriptive capabilities of spermatozoa by characterizing the solubilized DNA-dependent RNA polymerases present in separated head and tail fractions from ejaculated spermatozoa.

\section{Materials and Methods}

Trizma base, glycine, 2-mercaptoethanol, $\alpha$-amanitin; soybean trypsin inhibitor, calf thymus DNA, DEAE-Sephadex A-25, and ethidium bromide were purchased from Sigma Chemical Co. (St. Louis, Missouri). [ ${ }^{3} \mathrm{H}$ ]UTP (sp. act. $14-36 \cdot 8 \mathrm{Ci} / \mathrm{mmol}$ ) and Protosol were supplied by New 
England Nuclear Corporation (Boston, Massachusetts). Rifampicin was a product of Calbiochem (La Jolla, California). The unlabelled ribonucleoside triphosphates and enzymegrade sucrose were purchased from Schwarz/Mann Division (Becton Dickinson Co., Orangeburg, New York). Glycerol, spectro grade, was supplied by Eastman (Rochester, New York).

\section{Preparation of enzyme extracts from spermatozoa and mitochondria}

Highly purified fractions of sperm heads and tails were obtained as previously described (Hecht \& Williams, 1978). In brief, washed spermatozoa were sonicated and then layered over a discontinuous sucrose gradient containing $0.9 \mathrm{M}$ - and $2.0 \mathrm{M}$-sucrose. Preparations containing $97 \%$ heads and $99 \%$ tails were routinely obtained. When the spermatozoa were from a bull carrying the 'decapitated sperm defect' (Hancock \& Rollinson, 1949; Jones, 1962; Mann, 1969; Blom \& Birch-Anderson, 1970), the sonication step was omitted. Identical results were obtained with spermatozoa from either source.

Freshly isolated fractions of heads and tails from $2-5 \times 10^{8}$ spermatozoa or mitochondria prepared from $3 \mathrm{~g}$ calf liver as previously described (Hecht, 1975) were suspended in $4 \mathrm{ml}$ extraction buffer $\left(0.05 \mathrm{M}\right.$-Tris- $\mathrm{HCl}(\mathrm{pH} 7.9), 0.002 \mathrm{M}-\mathrm{MgCl}_{2}, 0.004 \mathrm{M}-2$-mercaptoethanol, $0.0001 \mathrm{M}$-EDTA, $25 \%$ glycerol) containing soybean trypsin inhibitor $(50 \mu \mathrm{g} / \mathrm{ml}), 0.1 \mathrm{M}$ dithiothreitol, and $1.5 \%$ sodium deoxycholate and incubated at $4{ }^{\circ} \mathrm{C}$ for $60 \mathrm{~min}$. Following incubation, the extract was sonicated at a setting of 4 for three 5-sec bursts interspersed with 15sec cooling intervals with a Branson sonicator (Model W185E).

The sonicate was diluted 3-fold with extraction buffer and centrifuged at $105000 \mathrm{~g}$ for 60 min at $4^{\circ} \mathrm{C}$ in a type 65 rotor in a Beckman L-5-50 centrifuge. The supernatant was decanted and either frozen under liquid nitrogen or loaded onto a DEAE-Sephadex column.

\section{Chromatography on DEAE-Sephadex}

DEAE-Sephadex was boiled for $2 \mathrm{~h}$ in the extraction buffer and cooled to room temperature. Columns of $1.4 \times 40 \mathrm{~cm}$ were poured and washed overnight with $500 \mathrm{ml}$ extraction buffer at $4^{\circ} \mathrm{C}$. Enzyme extracts $(8-30 \mathrm{ml})$ containing $0 \cdot 3-1 \cdot 1 \mathrm{mg}$ protein $/ \mathrm{ml}$ were adsorbed onto the column, washed with several column volumes of the extraction buffer and eluted with a linear gradient from $0.075 \mathrm{M}$ to $0.50 \mathrm{M}-\left(\mathrm{NH}_{4}\right)_{2} \mathrm{SO}_{4}$ in extraction buffer. Fractions $(0.7 \mathrm{ml})$ were collected into bovine serum albumin (final concentration $1 \mathrm{mg} / \mathrm{ml}$ ) and aliquots $(0.02 \mathrm{ml})$ were assayed for DNA-dependent RNA polymerase activity.

\section{Assay conditions for DNA-dependent RNA polymerases}

The standard reaction mixture $(0.25 \mathrm{ml})$ contained $20 \mu \mathrm{g}$ native calf thymus DNA, $20 \mu \mathrm{g}$ denatured calf thymus DNA, $10 \mu \mathrm{mol}$ Tris- $\mathrm{HCl}(\mathrm{pH} 7.9), 0.4 \mu \mathrm{mol}$ 2-mercaptoethanol, $1 \mu \mathrm{mol}$ $\mathrm{MgCl}_{2}, 1 \mu \mathrm{mol} \mathrm{MnCl}_{2}, 0.1 \mu \mathrm{mol}$ ATP, $0.1 \mu \mathrm{mol} \mathrm{CTP,} 0.1 \mu \mathrm{mol}$ GTP, $0.1 \mathrm{nmol}\left[{ }^{3} \mathrm{H}\right]$ UTP (250-1000 c.p.m./pmol) and an aliquot $(0.01-0.02 \mathrm{ml})$ of enzyme. After incubation at $37^{\circ} \mathrm{C}$ for $60 \mathrm{~min}$, the reaction was terminated by placing the assay tubes in ice and adding to each assay tube $2 \mathrm{ml}$ cold $10 \%(\mathrm{w} / \mathrm{v})$ trichloracetic acid (TCA) containing $10 \mathrm{~mm}$-sodium pyrophosphate. The precipitates were collected on glass-fibre filters (Whatman GF/A) and washed with $10 \mathrm{ml}$ $10 \%$ TCA followed by $10 \mathrm{ml} 95 \%$ ethanol. The filters were oven dried and counted in a toluenebased scintillation fluid in a liquid scintillation spectrometer. All samples were assayed in duplicate and values from samples incubated at $4^{\circ} \mathrm{C}$ were subtracted from those incubated at $37^{\circ} \mathrm{C}$. When the effect of inhibitors was tested, these compounds were added to the assay mixture before the addition of the enzyme. 


\section{Results}

When enzyme extracts were prepared from separated head and tail fractions and chromatographed on DEAE-Sephadex, a marked difference was observed in the profiles obtained (Textfig. 1). The head fraction was resolved into two peaks of RNA polymerase activity (hereafter called Polymerases $\mathrm{H} 1$ and $\mathrm{H} 2$ ) eluting at a concentration of about 0.11 and $0.15 \mathrm{M}$-ammonium sulphate (Text-fig. 1a). Four distinguishable RNA polymerase activities (hereafter called Polymerases T1, T2, T3 and T4), eluting at ammonium sulphate concentrations of about 0.11 , $0.15,0.255$ and $0.35 \mathrm{M}$, respectively, were observed when an extract prepared from isolated tails was chromatographed under identical conditions (Text-fig. 1b). When highly purified calf liver mitochondria, prepared by a multiple washing step followed by banding in sucrose (Hecht, 1975), were extracted and chromatographed on DEAE-Sephadex, four peaks (hereafter called Polymerases M1, M2, M3 and M4) eluting at the identical salt concentrations as those seen for extracts from sperm tails were obtained (Text-fig. 1c).

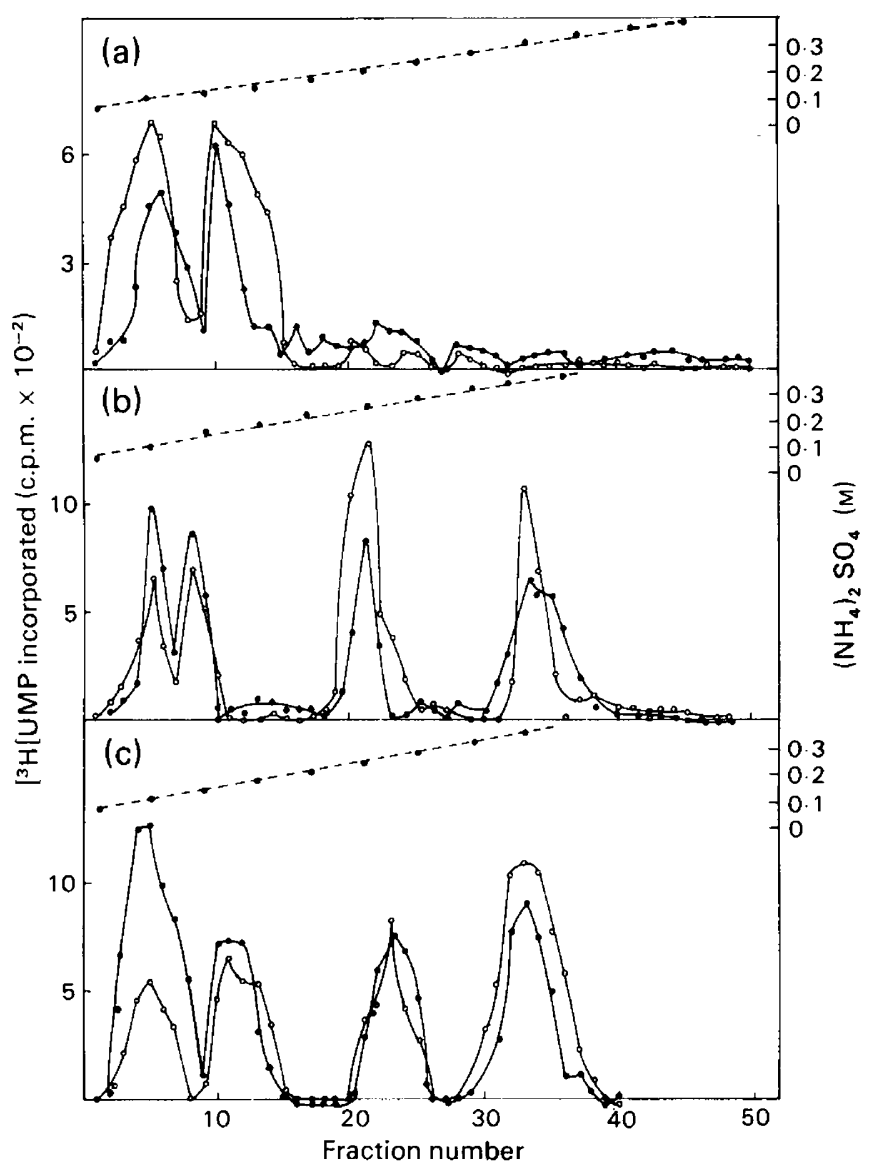

Text-fig. 1. Chromatography of DNA-dependent RNA polymerases from (a) sperm heads, (b) sperm tails and (c) liver mitochondria assayed with $1 \mathrm{~mm}-\mathrm{MgCl}_{2}(\mathrm{O})$ and $1 \mathrm{~mm}-\mathrm{MnCl}_{2}(\mathrm{O})$ on DEAE-Sephadex. Extracts were prepared from the separated heads and tails of $5 \times 10^{8}$ spermatozoa from a bull carrying the 'decapitated sperm defect' and from mitochondria isolated from $10 \mathrm{~g}$ calf liver as described in 'Methods'. Routinely, >100\% of the loaded RNA polymerase activity was recovered. The linear salt gradient is indicated by the broken line (-- ). 
All enzyme activities recovered from DEAE-Sephadex were dependent upon exogenous DNA, were stimulated by 2 -mercaptoethanol, and yielded maximal activity in the presence of all four ribonucleoside triphosphates (Table 1). Incorporation of RNA precursors was linearly dependent upon the concentration of the enzyme added and upon time of incubation. The product of each of the enzyme peaks was digestible by RNase A and was hydrolysed by sodium hydroxide. Results identical to those in Text-figs 1(b) and 1(c) were obtained when mitochondria were isolated from bovine heart by a $\mathrm{KCl}$ procedure (Sordahl, Johnson, Blailock, \& Schwartz, 1971) or when mitochondria from murine liver or heart were used.

Table 1. Requirements of RNA polymerases from bull sperm heads, sperm tails, and mitochondria

\begin{tabular}{lrrrrrrrrrr}
\hline & \multicolumn{10}{c}{ \% of standard reaction } \\
\cline { 2 - 10 } & H1 & H2 & T1 & T2 & T3 & T4 & M1 & M2 & M3 & M4 \\
\hline -DNA & 0 & 0 & 0 & 0 & 0 & 0 & 0 & 0 & 0 & 0 \\
-2-mercaptoethanol & 11 & 9 & 39 & 41 & 38 & 26 & 45 & 26 & 35 & 23 \\
-CTP, GTP, ATP & 19 & 4 & 9 & 22 & 13 & 13 & 15 & 21 & 26 & 13 \\
\hline
\end{tabular}

The reaction mixture and conditions of assay were as described in 'Methods' except for the indicated modification. The assays in which the addition of 2-mercaptoethanol was omitted contained a final concentration of between 0.16 and $0.32 \mathrm{~mm}-2$-mercaptoethanol. The standard reaction mixtures incorporated between 1217 and 2735 c.p.m./assay.

Qualitatively similar chromatographic results for sperm tails and mitochondria were obtained when extracts were prepared as follows: (1) the enzymes were solubilized with extraction buffer containing $0.5 \mathrm{M}-\mathrm{KCl}$ which was diluted before loading onto the DEAESephadex column; (2) the enzyme extract was incubated for $1 \mathrm{~h}$ at $37^{\circ} \mathrm{C}$ before loading; (3) the deoxycholate and dithiothreitol were deleted from the extraction buffer; and (4) the enzyme extract was incubated for $30 \mathrm{~min}$ with DNase $(100 \mu \mathrm{g} / \mathrm{ml})$ and RNase A $(50 \mu \mathrm{g} / \mathrm{ml})$ before loading. The addition to all buffers of three protease inhibitors, phenylmethyl sulphonyl fluoride at $1 \mathrm{mM}, \varepsilon$-amino n-caproic acid at $1 \mathrm{mM}, p$-aminobenzamidine at $1 \mathrm{mM}$ or the anti-oxidant, 2,6di-tertbutyl 4 hydroxymethylphenol at $50 \mu \mathrm{g} / \mathrm{ml}$, did not alter the chromatographic profiles of the extracts prepared from purified mitochondria or sperm tails.

To help differentiate between the multiple peaks of DNA-dependent RNA polymerases, the effect of divalent cations was studied. RNA Polymerases N1 and N2 were extracted and purified from liver nuclei as previously described (Farrell \& Hecht, 1975) and analysed in parallel with the enzymes from spermatozoa. When assayed at several concentrations of $\mathrm{MgCl}_{2}$, Polymerases $\mathrm{H} 1$ and $\mathrm{H} 2$ yielded activity profiles similar to those of Polymerases $\mathrm{N} 1$ and $\mathrm{N} 2$ (Text-fig. 2a). Polymerases T1, T3, M1 and M3 were better able to utilize $\mathrm{Mg}^{2+}$ than were Polymerases T2, T4, $\mathrm{M} 2$ and M4. In general, similar responses to increasing concentrations of $\mathrm{Mg}^{2+}$ were observed with enzymes from sperm tails and mitochondria eluting from DEAE-Sephadex at equivalent salt concentrations (Text-fig. 2a).

Text-fig. 2. Effects of different concentrations of (a) $\mathrm{MgCl}_{2}$, (b) $\mathrm{MnCl}_{2}$, (c) $\alpha$-amanitin and (d) rifampicin on the activity of RNA polymerases from various sources as indicated. Within each panel the polymerases are identified as $1(0), 2(0), 3(\times), 4(\Delta)$. The assays were performed as described in the 'Methods'; the $100 \%$ values ranged from 644 to 2765 c.p.m./assay. In (a) $\mathrm{MnCl}_{2}$ was omitted and $0.01 \mathrm{ml}$ aliquots of pooled peak fractions from DEAE-Sephadex containing $0.016 \mathrm{M}-\mathrm{MgCl}_{2}$ were assayed. Control experiments showed that residual $\mathrm{MgCl}_{2}$ and $\left(\mathrm{NH}_{4}\right)_{2} \mathrm{SO}_{4}$ in the enzyme samples did not significantly affect the assays. In (b) no additional $\mathrm{MgCl}_{2}$ was used. In (c) and (d) the compounds were added to the reaction mixture at $4{ }^{\circ} \mathrm{C}$ before addition of the enzyme. 

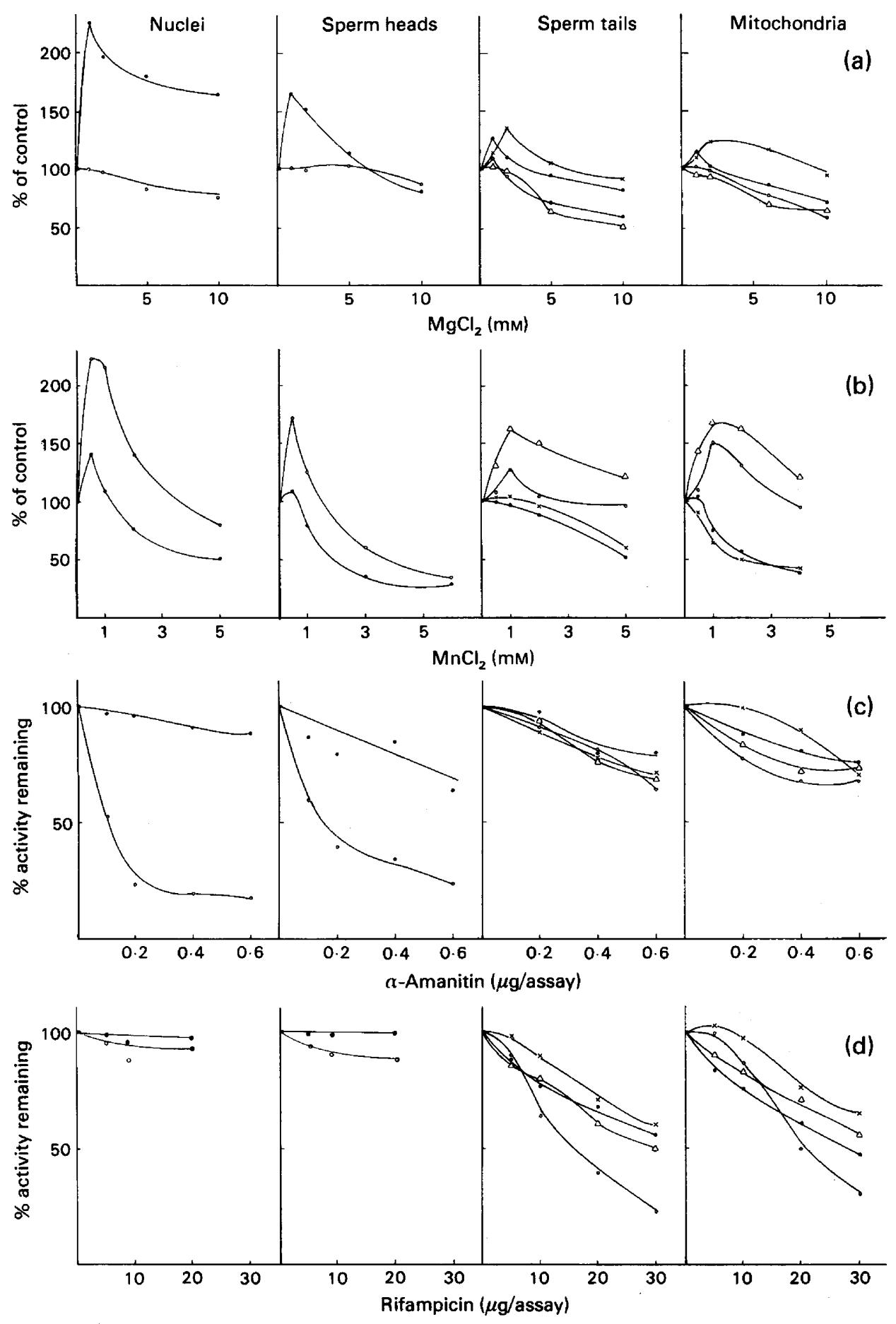
When the effect of $\mathrm{Mn}^{2+}$ was tested, similar responses between Polymerases $\mathrm{H} 1$ and $\mathrm{H} 2$ and Polymerases $\mathrm{N} 1$ and $\mathrm{N} 2$ were observed. Increasing concentrations of $\mathrm{MnCl}_{2}$ proved inhibitory to Polymerases T1, T3, M1 and M3 while T2, T4, M2 and M4 were stimulated by $\mathrm{Mn}^{2+}$ (Textfig. 2b).

When the solubilized RNA polymerases from somatic nuclei, sperm heads, sperm tails, and mitochondria were assayed at concentrations of $\alpha$-amanitin up to $2.4 \mu \mathrm{g} / \mathrm{ml}$, only Polymerases $\mathrm{H} 2$ and $\mathrm{N} 2$ were markedly inhibited (Text-fig. 2c). Polymerases T2 and M2 demonstrated inhibition kinetics similar to those of the other 3 enzymes found in somatic mitochondria and sperm tails, suggesting a difference between the enzyme eluting at $0.15 \mathrm{M}$-salt in the mitochondrial/sperm tail columns and the $\mathrm{H} 2 / \mathrm{N} 2$ enyzme (Text-fig. 2c). Mixing experiments in which Polymerases $\mathrm{H} 2$ and N2 were assayed in combination with M2 or T2 failed to detect the existence of a factor associated with the mitochondrial enzyme that made $\mathrm{N} 2$ or $\mathrm{H} 2$ insensitive to $\alpha$-amanitin.

When the solubilized RNA polymerases from sperm heads and tails were assayed in the presence of rifampicin, the enzymes from tails proved sensitive to this inhibitor while the head activities were not inhibited (Text-fig. $2 \mathrm{~d}$ ).

To test the effect of increasing concentrations of ammonium sulphate on the solubilized enzymes, they were assayed in the presence of $50 \mathrm{~mm}$ and $200 \mathrm{~mm}$ (Table 2). With the exception of the Polymerases $\mathrm{N} 1$ and $\mathrm{H} 1$ when assayed at $50 \mathrm{~mm}$-ammonium sulphate, all other RNA polymerase activities were depressed by the addition of the ammonium sulphate. Similar results were obtained when potassium chloride or sodium chloride was substituted for the ammonium sulphate, suggesting that the inhibition is an effect of higher ionic strengths.

Table 2. Effect of ammonium sulphate on DNA-dependent RNA polymerases from nuclei, sperm heads, sperm tails and mitochondria

\begin{tabular}{|c|c|c|c|c|c|c|c|c|c|c|c|c|}
\hline \multirow{2}{*}{$\begin{array}{l}\text { Ammonium sulphate } \\
(\mathrm{mM})\end{array}$} & \multicolumn{12}{|c|}{$\%$ of standard reaction } \\
\hline & N1 & $\mathrm{N} 2$ & H1 & $\mathrm{H} 2$ & T1 & $\mathrm{T} 2$ & T3 & T4 & M1 & M2 & M3 & M4 \\
\hline so & 102 & 54 & 103 & 56 & 59 & 79 & 65 & 74 & 65 & 72 & 69 & 61 \\
\hline 200 & 85 & 37 & 64 & 30 & 20 & 55 & 43 & 50 & 24 & 50 & 46 & 42 \\
\hline
\end{tabular}

The reaction mixture and conditions of assay were as described in 'Methods' except that $\left(\mathrm{NH}_{4}\right)_{2} \mathrm{SO}_{4}$ was added to the reaction mixture at $4^{\circ} \mathrm{C}$ before the addition of the enzyme. The standard reaction mixtures incorporated between 1217 and 2735 c.p.m./assay.

\section{Discussion}

In this report we demonstrate that highly purified populations of heads and tails from bovine spermatozoa contain DNA-dependent RNA polymerases, 2 species being associated with head fractions while 4 are distinguishable in tail preparations. Optimization and inhibitor studies indicate that the two RNA polymerases solubilized from sperm heads are similar to eucaryotic nuclear RNA polymerases 1 and 2. RNA polymerase 1 is an enzyme found in nucleoli that transcribes mainly ribosomal-like RNA while RNA polymerase 2 is a nucleoplasmic enzyme that is believed to synthesize predominantly DNA-like RNA (Chambon et al., 1970). RNA polymerase 1 activity is not significantly inhibited by $\alpha$-amanitin at concentrations up to 2.4 $\mu \mathrm{g} / \mathrm{ml}$ while RNA polymerase 2 is markedly inhibited by $\alpha$-amanitin (Roeder, 1974). The inhibition of RNA synthesis in isolated sperm heads by $\alpha$-amanitin suggests that RNA polymerase 2 is active in the isolated sperm head and thus the enzyme necessary to transcribe DNA-like RNA (messenger RNA) is present in the nucleus of the ejaculated spermatozoon. The inhibition of Polymerase $\mathrm{H} 2$ by $\alpha$-amanitin helps to differentiate it from the Polymerase T2 activity, an enzyme that otherwise shares many of the same chromatographic and reaction para- 
meters. Due to limited availability of enzyme, further purification and clarification of the relationship, if any, between the RNA polymerases, $\mathrm{H} 1$ and $\mathrm{T} 1$ and $\mathrm{H} 2$ and $\mathrm{T} 2$, was not undertaken. The minor peaks of RNA polymerase activity eluting from the DEAE-Sephadex column after the peak of Polymerase H2 (Text-fig. 1a) may represent the presence of nuclear RNA polymerase 3 in sperm heads or may be due to a low level of tail enzyme contamination in the head fraction.

The strong similarities between the enzymes isolated from sperm tails and heart or liver mitochondria provides additional evidence that the RNA synthesis observed in fractions of sperm tails is mitochondrial in origin. Enzymes responsible for mitochondrial transcription have been isolated and characterized from several sources including yeast (Scragg, 1971, 1974; Tsai, Michaelis \& Criddle, 1971; Wintersberger, 1972; Eccleshall \& Criddle, 1974), Neurospora (Kuntzel \& Schafer, 1971), Xenopus ovaries (Wu \& Dawid, 1972) and rat liver (Saccone, Gadaleta \& Gallerani, 1969; Reid \& Parsons, 1971; Mukerjee \& Goldfeder, 1973; Gallerani, de Giorgi, de Benedetto \& Saccone, 1976). Uncertainty exists over the number of species, forms, and properties of the DNA-dependent RNA polymerases from mitochondria. Wintersberger (1972) and Eccleshall \& Criddle (1974) have reported that yeast mitochondria contain several DNA-dependent RNA polymerases, some of which resemble nuclear RNA polymerases. Other investigators have isolated one DNA-dependent RNA polymerase from mitochondria (for review, see Saccone \& Quagliariello, 1975). These conflicting observations are further confused by the ability of a sucrose gradient-purified RNA polymerase from rat liver to yield 4 distinct activity peaks with different sensitivities to inhibitors after chromatography on DEAE-Sephadex (Mukerjee \& Goldfeder, 1973). In general, most investigators have isolated from mitochondria DNA-dependent RNA polymerases that tend to aggregate readily at low ionic strengths, are insensitive to $\alpha$-amanitin, and often are inhibited by rifampicin and high ionic strength (Saccone \& Quagliariello, 1975). In addition, mitochondria have been reported to contain a poly (A) polymerase, an enzyme that incorporates ATP into an acid-insoluble form without a DNA template (Rose, Morris \& Jacob, 1975; Gallerani et al., 1976).

An objection often raised to reports of multiple mitochondrial RNA polymerases is that it exceedingly difficult to obtain mitochondria free of nuclear and cytoplasmic contaminants. The tails of ejaculated spermatozoa provide an excellent system from which to extract mitochondrial enzymes since most of the cytoplasm of the maturing germ cells is lost during spermiogenesis. The identical RNA polymerase profile obtained from sperm tails or from purified somatic mitochondria makes it unlikely that the presence of multiple mitochondrial enzymes can be ascribed simply to nuclear or cytoplasmic contaminants. Furthermore, two of the enzymes present in the sperm tail preparation, T3 and T4, are not found at a significant level of activity associated with sperm heads.

Our report of multiple mitochondrial RNA polymerase activities raises the question of whether mitochondria really contain 4 distinct RNA polymerase enzymes or whether these multiple forms are due to bacterial contamination, proteolysis, aggregation or variable adsorption of an enzyme to mitochondrial components such as membrane or DNA. We feel bacterial contamination can be ruled out because (1) extensive washing procedures remove any contaminating cells from the spermatozoa (Fuster et al., 1977); (2) all washing and extraction solutions are sterile; (3) if bacterial contaminants were present in each preparation identical enzyme profiles with extracts from sperm tails and somatic mitochondria and a different profile with extracts from sperm heads would not be expected.

To determine whether proteolysis was creating multiple enzymes from one RNA polymerase, we attempted to stimulate proteolytic activities by incubating the enzyme extracts for up to $60 \mathrm{~min}$ at $37^{\circ} \mathrm{C}$. No significant changes were observed in the enzyme profile of these incubated extracts after chromatography on DEAE-Sephadex. Similarly, the addition of three protease inhibitors, phenylmethyl sulphonyl fluoride, $\varepsilon$-amino n-caproic acid, and $p$-aminobenzamide, to all isolation and extraction buffers failed to alter the chromatographic profile of 
mitochondrial extracts. This does not exclude, however, the possibility for the existence of a proteolytic activity that is resistant to the protease inhibitors under the conditions we tested.

Since mitochondrial RNA polymerases have been shown to aggregate at low salt concentrations (Saccone \& Quagliariello, 1975), we have been concerned that different aggregate states could create multiple forms of enzyme activity. Arguing against this possibility are the following observations: (1) when any peak of activity from a somatic mitochondrial or sperm tail DEAE-Sephadex column was rechromatographed, it eluted at the same salt concentration as it did initially, with no indication of the formation of multiple peaks and (2) no differences in the number of enzyme peaks were observed when $0.5 \mathrm{M}-\mathrm{KCl}$ was present in the extraction buffer or when $6 \mathrm{M}$-urea was present in all extraction and column buffers. The creation of several chromatographically distinguishable RNA polymerases from one enzyme that is adsorbed to variable amounts of nucleic acid or membrane remains a possibility despite the fact that incubation of the enzyme extract with DNase and RNase or the addition of the antioxidant, 2,6-di-tertbutyl 4 hydroxymethylphenol, did not change the elution profile of the muitiple RNA polymerases. We favour the interpretation that we are observing the binding of specific or non-specific factors to a core RNA polymerase, thereby creating multiple forms of enzymes that reproducibly elute from DEAE-Sephadex at different concentrations of salt.

Assaying highly purified populations of sperm heads and tails we observed that both fractions synthesized RNA using endogenous templates and enzymes (Hecht \& Williams, 1978). Although the heads and tails share many similar reaction parameters, the activities were distinguishable by several criteria. The synthesis associated with the heads was maximal at $37^{\circ} \mathrm{C}$ in the presence of $5 \mathrm{mM}-\mathrm{Mg}^{2+}$ while the tail fraction demonstrated maximal activity at $31^{\circ} \mathrm{C}$ and 10-50 mM- $\mathrm{Mg}^{2+}$. Tail synthesis was inhibited by atractyloside and rifampicin but was resistant to $\alpha$-amanitin and rifamycin SV. The RNA synthetic activity in the head fraction was resistant to inhibition by atractyloside but was markedly inhibited by $\alpha$-amanitin, rifampicin and rifamycin SV. We have previously been unable to determine if the RNA synthetic enzymes in sperm tails were insensitive to $\alpha$-amanitin or if this potent inhibitor of RNA polymerase 2 was unable to enter the mitochondrion. The studies we report here indicate that, at the level of enzyme purification tested, $\alpha$-amanitin only slightly decreased the activity of the RNA polymerases from sperm tails. In contrast, the activity of one of the sperm head enzymes, $\mathrm{H} 2$, is markedly depressed. We have previously reported that rifampicin inhibited RNA synthesis with similar inhibition kinetics in separated heads and tails (Hecht \& Williams, 1978). When solubilized enzymes were assayed in the presence of rifampicin, the activities from the tails were inhibited while the activities of the two enzymes from the head fraction were not depressed. This apparent paradox in which solubilized and in-situ sperm nuclear RNA polymerases demonstrate differential responses to rifampicin may be explained by enzyme or inhibitor interactions with other proteins in the sperm nucleus.

These results indicate that the nuclear genome and the mitochondria of the spermatozoon each contain DNA-dependent RNA polymerases. The role that these enzymes play in transcribing RNA essential for gamete maturation and post-fertilization events is unknown. However, Kaulenas \& Fairbairn (1968) and Foor (1970) have demonstrated that RNA synthesis by the male genome occurs at the time of fertilization in Ascaris, a time when the maternal genome is undergoing meiotic divisions. Longo \& Kunkle (1978) have reported that the paternal genome of fertilized sea-urchin eggs transcribes RNA at the time of fertilization. The presence of RNA polymerases associated with the head of the ejaculated spermatozoon may facilitate the transcription of RNA species from the paternally derived genome that are essential for post-fertilization development.

We thank the Eastern Artificial Insemination Cooperative for most generously supplying the normal bull semen and $\mathrm{Dr}$ H. M. Dott for the semen from a bull carrying the 'decapitated sperm defect'. This work was supported by National Science Foundation Grants Number PCM 7602094 and PCM 77-16483. 


\section{References}

Abraham, K.A. \& Bhargava, P.M. (1963) Nucleic acid metabolism of mammalian spermatozoa. Biochem. $J$. 86, 298-307.

Betlach, C.J. \& Erickson, R.P. (1976) 28 S and 18S ribonucleic acid from mammalian spermatozoa. $J$. exp. Zool. 198, 49-56.

Blom, E. \& Birch-Andersen, A. (1970) Ultrastructure of the "decapitated sperm defect" in Guernsey bulls. $J$. Reprod. Fert. 23, 67-72.

Chambon, P., Gissinger, F., Mandel, J.L., Kedinger, C., Gniazdowski, M. \& Meihlac, M. (1970) Purification and properties of calf thymus DNA-dependent RNA polymerases A and B. Cold Spring Harbor Symp. on Quant. Biol. 35, 693-707.

Eccleshall, R. \& Criddle, R.S. (1974) DNA-dependent RNA polymerases isolated from yeast mitochondria. Archs Biochem. Biophys. 164, 602-618.

Farrell, D. \& Hecht, N.B. (1975) DNA-dependent RNA polymerases from murine testis. Expl Cell Res. 93, $120-126$.

Foor, W.E. (1970) Spermatozoan morphology and zygote formation in nematodes. Biol. Reprod., Suppl. 2, 177-202.

Fuster, C.D., Farrell, D., Stern, F.A. \& Hecht, N.B. (1977) RNA polymerase activity in bovine spermatozoa. J. Cell Biol. 74, 698-706.

Gallerani, R., de Georgi, C., de Benedetto, C. \& Saccone, C. (1976) Contemporaneous isolation of Deoxyribonucleic acid-dependent Ribonucleic acid polymerase and poly (A) polymerase from rat liver mitochondria. Biochem.J. 157, 295-300.

Hancock, J.L. \& Rollinson, D.H.L. (1949) A seminal defect associated with sterility of Guernsey bulls. Vet. Rec. 61, 742-746.

Hecht, N.B. (1975) A DNA-directed DNA polymerase from murine liver mitochondria. Biochim. Biophys. Acta 414, 59-70.

Hecht, N.B. \& Williams, J.L. (1978) Synthesis of RNA by separated heads and tails from bovine spermatozoa. Biol. Reprod. 19, 573-579.

Jones, W.A. (1962) Abnormal morphology of the spermatozoa in Guernsey bulls. Br. vet. J. 118, 257261.

Kaulenas, M.S. \& Fairbairn, D. (1968) RNA metabolism of fertilized Ascaris lumbricoides egg during uterine development. Expl Cell Res. 52, 233-251.

Kuntzel, H. \& Schafer, K.P. (1971) Mitochondrial RNA polymerase from Neurospora crassa. Nature, New Biol. 231, 265-269.

Longo, F.J. \& Kunkle, M. (1978) Synthesis of RNA by male pronuclei of fertilized sea urchin eggs. J. exp. Zool. 201, 431-437.

MacLaughlin, J. \& Terner, C. (1973) Ribonucleic acid synthesis by spermatozoa from the rat and hamster. Biochem. J. 133, 635-639.
Mann, T. (1969) The science of reproduction. Nature, Lond. 224, 649-654.

Mukerjee, H. \& Goldfeder, A. (1973) Purification and properties of Ribonucleic acid polymerase from rat liver mitochondria. Biochemistry, N.Y. 12, 50965101.

Premkumar, E. \& Bhargava, P.M. (1972) Transcription and translation in bovine spermatozoa. Nature, New Biol. 240, 139-143.

Premkumar, E. \& Bhargava, P.M. (1973) The isolation and characterization of newly synthesized RNA and protein in mature bovine spermatozoa and effect of inhibitors on these syntheses. Indian J. Biochem. Biophys. 10, 239-253.

Reid, B.D. \& Parsons, P. (1971) Partial purification of mitochondrial RNA polymerase from rat liver. Proc. natn. Acad. Sci. U.S.A. 68, 2830-2834.

Roeder, R.G. (1974) Multiple forms of DNA-dependent RNA polymerase in Xenopus laevis. Isolation and partial characterization. J. biol. Chem. 249, 241-248.

Rose, K.M., Morris, H.P. \& Jacob, S.T. (1975) Mitochondrial poly (A) polymerase from a poorly differentiated hepatoma: purification and characteristics. Biochemistry, N.Y. 14, 1025-1032.

Saccone, C. \& Quagliariello, E. (1975) Biochemical studies of mitochondrial transcription and translation. Int. Rev. Cytology 43, 125-165.

Saccone, C., Gadaleta, M.N. \& Gallerani, R. (1969) RNA synthesis in isolated rat liver mitochondria. Eur. J. Biochem. 10, 61-65.

Scragg, A.H. (1971) Mitochondrial DNA-directed RNA polymerase from Saccharomyces cerevisae mitochondria. Biochem. Biophys. Res. Commun. 45, 701-706.

Scragg, A.H. (1974) A mitochondrial DNA-directed RNA polymerase from yeast mitochondria. In Biogenesis of Mitochondria, pp. 47-57. Eds A. M. Kroon \& C. Saccone. Academic Press, New York.

Sordahl, L.A., Johnson, C., Blailock, Z.R. \& Schwartz, A. (1971) The mitochondria. In Methods in Pharmacology, pp. 247-286. Ed. A. Schwartz. Appleton-Century-Croft, New York.

Tsai, M., Michaelis, G. \& Criddle, R.S. (1971) DNAdependent RNA polymerase from yeast mitochondria. Proc. natn. Acad. Sci. U.S.A. 68, 473-477.

Wintersberger, E. (1972) Isolation of a distinct rifampicin-resistant RNA polymerase from mitochondria of yeast, Neurospora, and liver. Biochem. Biophys. Res. Commun. 48, 1287-1294.

Wu, G. \& Dawid, I.B. (1972) Purification and properties of mitochondrial deoxyribonucleic acid polymerase from ovaries of Xenopus laevis. Biochemistry, N.Y. 11, 3589-3595.

Received 17 January 1979 